\title{
TELAAH TERHADAP KONSTRUKSI PROSES HUKUM YANG ADIL DALAM SISTEM PERADILAN PIDANA
}

\author{
Mahsun Ismail \\ Universitas Islam Indonesia, Email : mahsunismail09@gmail.com
}

\begin{abstract}
ABSTRAK
Sistem peradilan pidana (criminal justice system) merupakan sistem pengendalian kejahatan yang terdiri dari lembaga-lembaga kepolisian, kejaksaan, pengadilan, dan lembaga pemasyarakatan. Tujuan dari sistem peradilan pidana mencegah masyarakat menjadi korban kejahatan, menyelesaikan kasus kejahatan yang terjadi sehingga masyarakat puas bahwa keadilan telah ditegakkan dan yang bersalah diadili, mengusahakan agar mereka yang pernah melakukan kejahatan tidak lagi mengulangi perbuatannya. Namun disisi lain tidak jarang hak-hak tersangka kadangkala dikesampingkan dengan adanya tindakan diskriminasi maupun tindakan yang dilakukan oleh aparat penegak hukum yang menjurus pada self-incrimination. Hasil penelitian ini menunjukkan bahwa pemenuhan terhadap hak-hak tersangka merupakan ciri dari proses hukum yang adil yang berpijak pada rule of law.
\end{abstract}

Kata-kata kunci : Sistem peradilan pidana, keadilan, tersangka

\section{ABSTRACT}

Criminal justice system is a crime control system consisting of police, prosecutor, court, and prison institutions. The purpose of the criminal justice system prevents people from becoming victims of crime, resolves crimes that occur so that people are satisfied that justice has been upheld and those who are guilty are tried, seeking that those who have committed crimes no longer repeat their actions. But on the other hand it is not uncommon for the rights of suspects to be sometimes ruled out by the existence of discriminatory actions and actions taken by law enforcement officers that lead to self-incrimination. The results of this study indicate that the fulfillment of the rights of suspects is a feature of a fair legal process that rests on the rule of law.

Keywords: Criminal justice system, justice, suspects

\section{PENDAHULUAN}

Proses peradilan yang fair (adil) merupakan indikator dari terbangunnya masyarakat dan sistem hukum yang adil. Tanpa penerapan prinsip peradilan yang adil, orang -orang yang tak bersalah akan banyak memasuki sistem peradilan pidana dan kemungkinan besar akan masuk dalam penjara. Tanpa penerapan prinsip peradilan yang adil, hukum dan 
kepercayaan masyarakat terhadap hukum serta sistem peradilan akan runtuh. Di Indonesia sendiri, perjuangan menegakkan prinsip peradilan yang adil telah lama dimulai. Salah satu yang menjadi sebagai karya agung (masterpiece) dari bangsa Indonesia adalah UU No 8 Tahun 1981 tentang Hukum Acara Pidana (atau lebih sering disebut sebagai KUHAP). Sebab KUHAP adalah kitab Undang-Undang yang pertama kali diciptakan oleh bangsa indoensia sendiri. Bila dibandingkan dengan HIR, tampaknya substansi hukum acara pidana tahun 1981 lebih maju, khususnya yang bertalian dengan hak asasi tersangka/terdakwa. Hal ini dapat dibaca pada pasal-pasal atau asas-asas yang mengatur tentang hak-hak tersangka/ terdakwa seperti: asas-asas persamaan di depan hukum, yang terdapat dalam penjelasan umum butir 3, hak untuk segera diperiksa, hak untuk segera diperiksa, diajukan kep pengadilan dan diadili (Pasal 50 ayat 1, 2, dan 3), hak mendapat bantuan hukum bagi setiap tersangka/terdakwa (Pasal 54), hak untuk diberitahu oleh aparat penegak hukum mengenai sangkaan yang ditujukan kepadanya (Pasal 51), hak untuk memberikan secara bebas (Pasal 52), serta asas praduga tidak bersalah yang terdapat dalam pasal penjelasan umum butir 3c KUHAP (Tahir, 2010: 2).

Dalam sistem peradilan pidana, due process of law diartikan sebagai suatu proses hukum yang baik, benar dan adil. Pengadilan yang adil merupakan suatu usaha perlindungan paling dasar untuk menjamin bahwa para individu tidak dihukum secara tidak adil. Proses hukum yang demikian terjadi apabila aparat penegak hukum yang terkait dengan proses tersebut, tidak hanya melaksanakan tugasnya sesuai dengan aturan yang ada, tetapi juga memastikan agar semua hak tersangka/terdakwa yang telah ditentukan diterapkan. Proses hukum adil juga wajib mengimplementasikan asas-asas dan prinsip-prinsip yang melandasi proses hukum yang adil tersebut (meskipun asas atau prinsip tersebut tidak merupakan peraturan hukum positif (Muladi, 1998: 5).

Selepas pemberlakuan KUHAP, berbagai instrument hak asasi manusia juga diadopsi dan menjadi bagian dari sistem hukum nasional, diantaranya adalah United Nations Convention Against Corrruption, International Convention Against Torture, dan International Covenant on Civil and Political Rights. Dalam proses peradilan pidana saat ini, paradigma yang ingin dibangun adalah warga negara yang menjadi tersangka atau 
terdakwa, tidak dapat lagi dipandang sebagai "obyek" tetapi sebagai "subyek" yang mempunyai hak dan kewajiban berdasarkan hukum. Sesungguhnya, hak-hak tersangka atau terdakwa sebagaimana yang telah dikemukakan diatasa sekaligus merupakan rambu-rambu bagi aparat penegak hukumk agar tidak lagi melakukan tindakan-tindakan yang bertentangan dengan hak-hak tersangka. Seperti tindakan penyiksaan diluar batas perikemanusiaan yang acapkali dilakukan oleh penyidik demi memperoleh pengakuan dari tersangka. Kondisi ini memang seyogyanya harus diakhiri, karena disamping merupakan tindakan yang merendahkan harkat dan martabat manusia, hal ini juga, dapat berakibat pengakuan tersebut diabaikan oleh pengadilan dengan alasan diperoleh secara tidak sah karena dilakukan dengan cara kekerasan atau ancaman kekerasan (Tahir, 2010: 2). Namun, hukum sekali lagi adalah produk politik pada masa itu. Meskipun dinyatakan sebagai karya agung dari bangsa Indonesia, proses politik otoriter pada masa itu juga banyak mempengaruhi ketentuan-ketentuan dalam KUHAP. Selain ketentuan KUHAP yang masih belum sempurna dalam melindungi kepentingan tersangka/terdakwa, dan juga korban, pada praktiknya usaha perlindungan yang tercantum dalam KUHAP sering diabaikan tidak hanya oleh para actor dalam sistem peradilan pidana, namun juga oleh Pengadilan.

\section{PEMBAHASAN}

1. Sejarah Peradilan yang Fair (Adil)

Pada hakikatnya proses peradilan yang fair yang ada dalam hukum acara pidana sebenarnya bertalian dengan asas legalitas di hukum pidana meteriilnya yakni sama-sama hendak melindungi hak-hak warga Negara, dengan cara membatasi kekuasaan pemerintah (penguasa) serta mengaturnya dalam tataran undang-undang. Awal mula dari munculnya proses peradilan yang fair sebenarnya sudah ada pada zaman Rasulullah SAW, yakni dengan dibuatnya Piagam Madinah antara umat islam dengan kaum yahudi. Salah satu poin dari isi dari Piagam Madinah tersebut penghargaan terhadap hak-hak fundamental dari manusia yang notabene berbeda-beda suku, jenis, dan bangsa (Marzuki, 2018). Dengan perjalanan waktu, proses hukum yang fair ini muncul pada tataran piagam Magna Charta di Inggris pada tahun 1215 dan rancangan undang-undang (Bill Of 
Right 1628), yang selanjutnya diatur pada tataran undang-undang (Habeas Corpus Act 1679).

Ternyata, waktu yang dibutuhkan untuk mengartikulasikan gagasan tentang perlunya jaminan perlindungan hak-hak warga Negara Inggris, dengan cara membatasi kekuasaan raja (termasuk kewenangan hakim) memerlukan sekitar 4,5 (empat setengah) abad, yakni sejak dibuatnya Magna Charta pada tahun 1215, Bill Of Right pada tahun 1628, sampai Habeas Corpus Act pada tahun 1679. Rentan waktu yang sangat lama untuk mengartikulasi dan mengkulminasikan suatu gagasan (Setyo, 2014: 26). Tidak mengherankan, apabila gagasan perlunya jaminan perlindungan hak-hak warga Negara, dengan cara membatasi kekuasaan raja dan kewenangan hakim yang sudah mencapai puncaknya di Inggris menjadi sumber inspirasi bagai para pemikir perancis untuk menumbuhkan kembangkan gagasan tersebut. Gagasan tersebut kemudian digunakan untuk melakuka kritik dan penolakan terhadap keabsolutan kekuasaan raja dan kewenangan hakim dengan peradilan pidana arbitrium juridisnya. Revolusi perancis tersebut menghasilkan Code Penal yang kemudian hari menjadi sumber kodifikasi hukum dibanyak Negara modern, antara lain Belanda dan Indonesia.

Berdasarkan konstitusi Perancis, perlindungan terhadap seseorang tidak hanya menyangkut hukum pidana dalam pengertian hukum pidana materiil semata tetapi juga dalam pengertian hukum pidana formil. Bahkan perlindungan terhdap kepentingan individu dari proses hukum yangs sewenang-wenang mendapat perhatian yang lebih utama dengan ketentuan dalam Pasal 7. Hal ini dapat dipahami karena dalam konteks hukum acara pidana, sedikit-banyaknya terjadi pengekangan terhdap hak asasi manusia (Hiarej, 2014: 63) Pada tahun 1948, tercetuslah Pernyataan Umum tentang Hak-Hak Asasi Manusia (Universal Declaration Of Human Right) yang di deklarasikan pada rapat umum PBB, kemudian diatur juga dalam konvensi eropa untuk perlindungan hak-hak asasi manusia dan kebebasan-kebebasan fundamental (European Convention For The Protection Of Human Rights And Fundamental Fredoms) pada tahun 1950 yang diberi title No Punishment Without Law, aturan yang hampir sama terdapat dalam Konvenan Internasional Tentang Hak-Hak Sipil dan Politik (United Nations International Covenant on Civil and Politic Rights) pada tahun 1966 yang 
sering disebut dengan ICCPR.

2. Miranda Warning terhadap Amandemen Konstitusi Amerika Serikat

Peringatan Miranda (Miranda warning), merupakan peringatan yang harus dilakukan atau diberikan oleh kepolisian kepada tersangka kriminal yang akan ditahan dalam penegakan hukum di Amerika Serikat. Peringatan ini harus dilakukan sebelum kepada pihak tersangka diajukan pertanyaan tentang apa yang terjadi atau peristiwa kejahatan sebelum interogasi tersangka (Wikipedia, 2018). Sebab karena penangkpan dan penahanan seseorang dalam suatu proses pidana merupakan tindakan membatasi hak kemrdekaan (liberty) seseorang, maka hal tersebut hanya dapat dilakukan berdasarkan suatu proses hukum yang adil (due process of law). Proses hukum yang adil ini dimunculkan dalam bentuk pembatsan-pembatasan kepada penyidik terhadap pelaksanaan proses penangkapan atau penyidikan dan penahanan serta proses-prosess yang berkaitan dengannnya, seperti penyidikan, penuntutan, proses pengadilan, pencekalan, penggeledahan, dan penyitaan.

Dalam ilmu hukum, pembatasan-pembatasan terhadap proses pengkapan dan penahanan, dan sebagainya tersebut antara lain muncul dalam bentuk-bentuk sebgai berikut (Fuadi, 2015: 73) yakni :

a. Pembatasan terhadap penangkapan (misalnya pada prinsipnya dilakukan harus dengan suatu surat perintah yang sah).

b. Pelarangan terhdap penyitaaan dan penggeledahan yang tidak logis

c. Pelarangna terhdap pemaksaan pemberian pengakuan yang bertentangan dengan kepentingan pemberi pengakuan tersebut

d. Memberikan atau memperingatkan tersangka akan hak-haknya untuk mendapatkan pembelaan dari advokat.

e. Melarang penggunaan pemaksaan atau cara-cara yang tidak layak lainnya dalam proses penyidikan pidana

Pengaruh Miranda warning terhadap konstitusi Amerika Serikat bisa kita lihat pada Amandemen ke V (kelima) yang menyatakan bahwa" Tidak ada orang boleh ditahan untuk mempertanggungjawabkan suatu kejahatan yang dianca dengan hukuman mati, atau kejahatan keji lainnya, kecuali atas pengajuan atau tuntutan dari suatu Juri Agung, kecuali dalam perkara-perkara yang timbul di dalam angkatan darat atau laut, atau di kalangan Milisi, ketika 
benar-benar dalam dinas, di masa perang atau bahaya umum; juga tidak ada orang akan dikenai ancaman jiwa atau anggota badan dua kali untuk tindak pidana yang sama; juga tidak akan dipaksa menjadi saksi melawan dirinya sendiri dalam suatu perkara kejahatan; juga tidak akan dihilangkan jiwanya, kebebasannya, atau miliknya, tanpa proses hukum yang semestinya; juga milik pribadi tidak akan diambil untuk dipakai untuk keperluan umum, tanpa penggantian yang adil". Sehingga Miranda Warning diterapkan dalam proses interogasi penyidikan, karena dalam tahap tersebut pihak tersangka dalam suasana dirampas atau dibatasi kebebasannya. Sehingga dengan adanya Miranda warning telah terjadi pergeseran paradigma yuridis terhadap hokum acara pidana di Negara amerika khususnya dibidang pembuktian sebagaimana berikut (Fuadi, 2015: 81-82) adalah :

a. Terjadi pergeseran paradigm yuridis dari pembuktian berdasarkan pengakuan tersangkakepada pengakuan berdasarkan alat-alat bukti lain, termasuk alat bukti nonkonvensional seperti tes DNA, sidik jari, dan kamera TV pengintai.

b. Terjadi pergeseran paradigm yuridis dari pengakuan tersangka berdasarkan kepada unsur paksa atau setengah paksa, kepada pengakuan tersangka secara sukarela

Adanya Miranda warning tersebut aparat penegak hokum tidak serta merta bisa menagkap, mengintrogasi terhadap tersangka untuk mendapatkan informasi tanpa adanya prosedur yang benar, hal itu diharapkan agar didapatinya unsur keadilan (fairness) bagi tersangka. Sehingga di amerika serikat aparat penegak hokum untuk menangkap tersangka yang diduga melakukan tindak pidana, maka kepada orang tersebut oleh aparat penegak hukum tersebut wajib diucapkan peringatan Miranda, yang berisikan kata-kata sebagai berikut (Fuadi, 2015: 82):

a. That you a right to remain silent.

b. That any statement you do make may be used as evidence against you

c. That you have a right to the presence of an attorney

d. That if you can not afford an attorney, one will be appointed for you prior to any questioning if you so desire

Yang artinya sebagai berikut: 
a. Tersangka mempunyai hak untuk tetap diam selama proses interogasi/penyidikan

b. Segala pernyataan yang dibuat oleh tersangka dalam proses introgasi mungkin akan digunakan sebagai bukti yang bertentangan dengan kepentingan tersangka tersebut.

c. Tersangka mempunyai hak untuk mendapatkan pembela.

d. Jika tersangka tidak sanggup membayar advokat, kepada tersangka dapat disediakan advokat sejak sebelum proses introgasi dilakukan.

Keharusan mengucapkan kalimat diatas oleh aparat penegak hokum harus secara jelas dikatakan kepada tersangka ketika menangkap tersangka yang selanjutnya disebut sebagai aturan Miranda (Miranda rule). Dengan demikian, berdasarkan aturan Miranda tersebut, maka kepada seseorang tersangka tidak boleh dipaksa-paksa untuk mengakui dan menceritakan apa-apa yang telah diperbuatnya dalm hubungan dengan tin dak pidana yang dituduhkan kepadanya. Apalagi jika dipaksa-paksa dengan cara melakukan penganiayaan, ancaman, dan hal-hal yang bersifat memaksa atau tindakan yang tidak layak yang lainya, baik itu secara fisik maupun psikis.

Sejatinya, aturan Miranda (Miranda rule) adalah suatu bentuk peringatan berkenaan dengan hak-hak tersangka yang wajib diberikan dan diucapkan oleh para penegak hukum kepada tersangka ketika tersangka tersebut ditangkap dan ditahan untuk keprluan penyidikan, dimana tanpa penyebutan dengan tegas peringatan tersebut dihadapan tersangka, segala keterangan tersangka yang merugikan tersangka yang bersangkutan tidak boleh dipergunakan sebagai bukti dipengadilan. Wayne $\mathrm{R}$ dalam bukunya LaFave sebagaimana dikutip oleh Munir Fuady, dia mengatakan nilai plus dari penerapan doktrin Miranda warning sebagai berikut (Fuadi, 2015: 80-81)):

a. Penerapan doktrin Miranda dapat menjadi symbol penerapan prinsip due process misalnya symbol anti penindasan terhadap kaum lemah atau kaum miskin.

b. Penerapan doktrin Miranda warning dapat menjadi peringatan dan wadah pembelajaran kepada pihak penyidik pidana untuk selalu menghormati hak-hak dari tersangka pidana. 
c. Penerapan doktrin Miranda dapat menjadi pemberi arahan yang jelas dan gamblang kepada pihak penyidik untuk tidak melanggar hak-hak tersangka dalam setiap detail dari proses introgasi pidana. Tanpa doktrin Miranda, pihak penyidik dangat sulit untuk menafsirkan mana diantara tindakan-tindakannya dalam prose introgasi yang dianggap melanggarf proses hukum yang adil (due process of law).

d. Doktrin Miranda mempermudah pihak pengadilan untuk menilai dan memutuskan apakah ada diantara tindakan yang telah dilakukan oleh para penyidik yang melanggar hak asasi manusia.

Berdasarkan penjabaran diatas, Miranda warning mempunyai andil besar terhadap amandemen konstitusi Amerika Serikat yang pada intinya merupakan manifestasi pada perlindungan hak-hak tersangka agar dapat diperlakukan secara adil (due process of law) serta mempunyai hak untuk didampingi penasehat huikum pada setiap tahap pemeriksaan.

3. Konsep Peradilan yang Fair dalam Sistem Peradilan Pidana

Proses peradilan yang fair (adil) merupakan intisari atau roh dari sistem peradilan pidana, mengingat bahwa sistem peradilan pidana adalah wadah dari proses peradilan yang fair (adil) sehingga tidak mungkin membicarakan proses hukum yang adil tanpa adanya system peradilan pidana itu sendiri yang ditandai dengan adanya perlindungan terhdap hak-hak tersangka dan terdakwa.

Muladi memandang sistem peradilan pidana sebagai suatu jaringan (network) yang mengoprasionalisasikan hukum pidana sebagai sarana utamanya. Dalam hal ini dapat berupa hukum materiil, hukum pidana formil, dan hukum pelaksanaan pidana (Zaidan, 2016: 293). Sementara itu, Barda Nawawi Arief mengartika system peradilan pidana sebagai suatu proses penegakan hukum pidana. Oleh karena itu perhubungan erat dengan perundang-undangan pidana itu sendiri, baik hukum pidana substantive maupun hukum acara pidana. Pada dasarnya, perundang-undangan pidana merupakan penegaklan hukum pidana in abstracto yang diwujudkan ke dalam penegakan hukum in concreto (Tahir, 2010: 9.

Berdasarkan penjabaran diatas, jelaslah relevansi system peradilan 
pidana dengan proses hukum yang fair. Sebab, system peradilan pidana sebagai sistem penegakan hukum dengan sendirinya harus mencerminkan adanya perlindungan terhdap hak-hak tersangka/ terdakwa. Sedangkan hak-hak tersangka atau terdakwa yang terdapat dalam sistem peradilan pidana merupakan prasyarat atas terselenggaranya proses peradilan yang fair. Secara teoritik, "due process of law" adalah jalan bagi proses peradilan yang fair dan manusiawi (FM) dalam setiap tahap peradilan (procedural design), baik pada tahap pra-ajudikasi (pre-ajudication), tahap ajudikasi (ajudication) dan tahap purna-ajudikasi (postajudication). Ketiga proses peradilan itu harus berjalan dan dijalankan dengan menjunjung tinggi hukum dan kemanusian sekaligus (Marzuki, 2007: 374).

Berhubungan dengan konsep peradilan yang fair Tobias dan Peterson menambahkan bahwa proses hukum yang adil (due process of law) yang berasal dari dari inggris, dokumen magna charta, 1215 merupakan "constituenal guaranty.... that no person will be deprived of live, liberty of property for reason that are arbitrary... protects the citizen against arbitrary actions of government". Oleh karena itu, unsur-unsur minimal dari proses peradilan yang fair harus memenuhi 6 kriteria sebagai berikut, yaitu: notice, hearing, counsel, defence, evidence and fair and impartial court (Setiawan, 2018). Berkaitan dengan system peradillan pidana, packer memperkenalkan dua model yakni Cirme Control Model dan Due Process Model yang keduanya bertumpu pada system perlawanan (The Adversary System) atau di Negara system Anglo Saxion. Berbeda dengan di Indonesia yang menganut system Civil Law tentunya system yang digunakan adalah system selidik (Inquisitorial Sistem). Dalam system selidik ini, peranan hakim punya andil besar, karena merekalah yang membangun dan memutus perkara. Untuk itu maka perlu adanya kemandirian yudisial yang merupakan prasyarat terselenggaranya prinsip proses hukum yang fair, kemandirian yudisial dapat menggunakan empat model yakni, crime control model, due process model, family model, dan pengayoman model. Berdasarkan pelbagai macam model di system peradilan pidana dalam rangka menegakkan proses hukum yang fair, harus disediakna seperangkat hak yang dapat digunakanoleh tersangka dan terdakwa agar dapat terhindar dari tindakan sewenang-wenang pidahk penguasa. Hak tersebut antara lain, hak untuk membela diri serta adanya suatu peradilan yang jujur dan tidak 
memihak.

4. Asas-Asas Hukum Pidana dalam Peradilan yang Fair

Perwujudan dari proses peradilan yang fair tertuang dalam berbagai asas-asas sebagai berikut:

a. Asas praduga tak bersalah (presumption of innocent). Adalah prasyarat utama menetapkan bahwa suatu proses telah berlangsung secara jujur, adil, dan tidak memihak artinya bukan berdasarkan pada putusan hakim yang bersifat inkrach untuk dapat diakatakan seseorang bersalah atau yang disebut dengan asas presumption of innocence. Maka jelas dan sewajarnya apabila terdakwa karena kedudukannya wajib mendapat hak-haknya. Asas presumption of innocent merupakan asas hukum karena menjadi landasan sekaligus menjadi ratio legis lahirnya peraturan atau undang-undang yang berkaitan dengan hukum acara pidana seperti hak untuk memperoleh bantuan hukum, hak untuk mengajikan saksi yang meringankan, hak untuk melakukan upaya hukum dan seterusnya. Asas praduga tidak bersalah melahirkan ketentuan hukum lanjutan sebagai penjabran dari asas itu dalam rangka melindungi hak-hak tersangk atau terdakwa (Zaidan, 2015: 50).

Asas praduga tak bersalah pada dasarnya merupakan manifestasi dari fungsi peradilan pidana yang melakukan pengambil alihan kekerasan atau sikap balas dendam oleh suatu institusi yang ditunjuk oleh Negara. Dengan demikian, semua pelanggaran yang dilakukan oleh seseorang harus diselesaikan sesuai dengan prosedur hukum yang berlaku. Selanjutnya, Munif Fuady menjelaskan bahwa praduga dalam hukum pidana tersebut sebenarnya hanya merupakan suatu asas hukum yang lebih merupakan penentuan oleh hukum bahwa pihak penuntut yang harus membuktikan kesalahan mereka. Sebelum terbukti, tersangka tidak boleh diperlakukan secara sewenang-wenang yang dapat melanggar hak-hak konstitusionalnya meskipun dalam batas-batas tertentu kemerdekaan sudah mulai dibatasi, seprti dia sudah boleh diborgol atau ditahan (Fuadi, 2012: 51).

b. Asas persamaan di depan hukum (equality before the law). Adalah asas persamaan kedudukan di depan hukum merupakan salah satu aspek penting dalam proses peradilan yang fair. Karena tanpa adanya asas ini 
tidak munkin proses peradilan yang fair dapat ditegakkan dalam system peradilan pidana. Oleh karena itu setiapwarga Negara, teak terkecuali tersangka/terdakwa harus diberi kesempatan yang sama untuk menggunakan hak-hak yang telah ditentukan oleh undang-undang, seprti hak untuk memperoleh bantuan hukum, hak untuk memberikan keterangan secara bebas serta hak untuk diadili oleh peradilan yang jujur dan tidak memihak.

Pemberlakuan asas persamaan di depan hukum dalam proses peradilan pidana di Indonesia, tampaknya masih belum secara utuh dilaksanakan, hal itu bisa kita lihat bagaimana tindakan disparitas baik dalam penjatuhan sanksi pidana maupun perlkuan antara yang satu dengan yang lain masih sangat terasa. Ketika rakyat kecil dijatuhi pidana oleh pengadilan, maka serta merta ia harus menjalani pidana, sebaliknya, bila pihak yang mempunyai kekuasaan atau massa dijatuhi pidana, mereka seolah-olah masih diberi kesempatan untuk mencari justifikasi agar tetap menghirup udara diluar penjara.

\section{Peradilan yang Fair pada Pra, Selama, Pasca Peradilan Pidana}

Proses peradilan yang fair memang diharapkan dipraktekkan dalam setiap proses atau tahapan dalam system peradilan pidana, karena sudah dijelaskan diatas bahwa seseorang yang menjadi tersangka ataupun terdakwa atas suatu tindak pidana dalam keadaan dirampas kebebasannya, maka sudah tentu aparat penegak hukum semaksimal mungkin untuk tidak mengurangi atau melanggar hak-hak yang sudah diatur dalam undang-undang. KUHAP tidak menghendaki suatu proses peradilan dimana seseorang tersangka sudah dijatuhi putusan bersalah sebelum prosesnya dimulai (Rukhmini, 2003: 83). Ketika aparat penegak hukum dalam menjalankan fungsi dan wewenangnya maka perlu mengaktulisasikan proses peradilan yang fair dalam tiga tahap. Pertama, praperadilan (Pre-adjudication) pidana, bahwa aparat penegak hukum saat melakukan tindakan penangkapan, penahanan, maupun saat melakukan penyidikan dan penuntutan haruslah menjunjung tinggi asas praduga tidak bersalah dan persamaan di depan hukum yang merupakan asas dari proses hukum yang adil. Kemudian, hak tersangka untuk memberikan keterangan secara bebas dan hak tersangka mendapat bantuan hukum 
sesuai pilihannya serta hak tersangka untuk berhubungan ataupun berbicara dengan penasihat hukumnya setiap saat, meskipun KUHAP diperlukan untuk melindungi dan menjamin hak-hak tersangka, akan tetapi sering kali ketentuan ini masih sering dilanggar karena ketentuan yang tidak jelas (Dehoop, 2013: 37).

Ketentuan Pasal 54 KUHAP menyebutkan bahwa guna kepentingan pembelaan, tersangka atau terdakwa berhak mendapat bantuan hukum dari seorang atau lebih penasihat hukum selama dalam waktu dan pada setiap tingkat pemeriksaan, menurut tata cara yang ditentukan dalam undangundang ini. Selanjutnya Pasal 55 KUHAP menentukan bahwa untuk mendapatkan penasihat hukum seperti yang tersebut dalam Pasal 54, tersangka/terdakwa berhak memilih sendiri penasihat hukumnya dan penasihat hukum diperkenankan mengunjungi dan berbicara dengan tersangka. Kedua, selama proses persidangan (adjudication) terdapat jaminan sepenuhnya hak-hak kedua belah pihak. Hak penuntut umum adalah mendakwa dan hak terdakwa membela dirinya terhadap dakwaan. Jaminan yang penuh ini harus diberikan oleh pengadilan dan dalam kenyataannya hanya dapat berlangsung apabila selalu dapt meyakini kenetralan dan kebebasan hakim-hakimnya. Suatu proses yang adil dimana ia terdapat keyakinan akan adanya pengadilan yang bebas adalah sangat penting bagi rasa aman masyarakat, tidak kalah penting dari usaha menanggulangi kejahatan (Raharjo, 2008: 94).

Dalam tataran ideal, untuk mewujudkan putusan hakim yang memenuhi harapan pencari keadilan, yang mencerminkan nilai-nilai hukum dan rasa keadilan masyarakat, ada beberapa unsur yang harus dipenuhi dengan baik. Gustav Radbruch mengemukakan idealnya dalam suatu putusan harus memuat idee des recht, yang meliputi 3 unsur yaitu keadilan (Gerechtigkeit), kepastian hukum (Rechtsicherheit) dan kemanfaatan (Zwechtmassigkeit). Ketiga unsur tersebut semestinya oleh Hakim harus dipertimbangkan dan diakomodir secara proporsional, sehingga pada gilirannya dapat dihasilkan putusan yang berkualitas dan memenuhi harapan para pencari keadilan (Sutiyoso, 2010: 227).

Perwujudan dari asas praduga tak bersalah ialah bahwa seorang terdakwa tidak dibebani kewajiban pembuktian bahwa dirinya bersalah 
(Pasal 66 KUHAP). Justru karena Penuntut Umum yang mengajukan tuduhan terhadap terdakwa, maka Penuntut Umumlah yang dibebani tugas untuk membuktikan kesalahan terdakwa dengan upaya-upaya pembuktian yang diperkenankan oleh Undang-undang. Terdakwa dapat menyiapkan pembelaan dari apa yang didakwakan kepadanya. Agar terdakwa dapat menyiapkan pembelaanya, terdakwa berhak diberitahu tentang apa yang didakwakan kepadanya baik dalam proses penyidikan maupun dalam proses persidangan dalam bahasa yang dimengertiolehnya. Ada kalanya terdakwa yang diperiksa tidak dapat memahami bahasa Indonesia dengan baik dan benar, entah karena terdakwa orang asing atau orang suku pedalaman. Untuk itu jika terdakwa tidak dapat mengerti dengan baik bahasa yang disampaikan kepadanya, terdakwa berhak mendapatkan juru bahasa yang akan menyampaikan penjelasan tetang apa yang didakwakan kepadanya. Hal ini seperti yang diatur dalam pasal 51 KUHAP yang berbunyi:

Untuk mempersiapkan pembelaan :

a. Tersangka berhak untuk diberitahukan dengan jelas dalam bahasa yang dimengerti olehnya tentang apa yang disangkakan kepadanya pada waktu pemeriksaan dimulai.

b. Terdakwa berhak untuk diberitahukan dengan jelas dalam bahasa yang dimengerti olehnya tentang apa yang didakwakan kepadanya

Setiap terdakwa memiliki hak untuk diperiksa oleh Pengadilan secara adil dan terbuka untuk umum seperti yang dipaparkan dengan jelas dalam pasal 64 KUHAP. Pengadilan yang terbuka untuk umum akan mengurangi potensi terjadinya kecurangan atau penyalahgunaan wewenang di dalam persidangan karena dapat dipantau oleh masyarakat luas. Meskipun demikian, ada beberapa proses pemeriksaan di pengadilan yang tidak dapat dilakukan terbuka untuk umum, yakni dalam hal terdakwanya adalah seorang anak dan terhadap perkara kesusilaan. Ketiga pasca peradilan (Post-Adjudication), setelah selesai proses acara pemeriksaan di persidangan maka selanjutnya hakim akan memberikan putusan terhadap terdakwa. Apabila terdakwa menerima putusan hakim tersebut maka akan dilaksanakan proses pemidaan, namun jika terdakwa tidak menerima dapat melakukan upaya hukum. 
Adapun yang dimaksud dengan upaya hukum oleh yaitu suatu usaha melalui saluran hukum dari pihak-pihak yang merasa tidak puas terhadap keputusan hakim yang dianggapny kurang adil atau kurang tepat. Sedangkan dalam pedoman pelaksanaan KUHAP menerangkan bahwa upaya hukum itu hak terdakwa atau penuntut umum untuk tidak menrima putusan pengadilan (Sofyan, 2013: 287). Dalam Pasal 196 ayat (3) KUHAP menyebutkan, "segera sesudah putusan pemidanaan diucapkan, hakim ketua siding wajib memberitahukan kepada terdakwa tentang segala yang menjadi haknya yaitu:

a. Hak segera menerima atau menolak putusan;

b. Hak mempelajari putusan

c. Hak meminta penangguhan putusan untuk mengajukan grasi dalam hal menerima putusan;

d. Hak mengajukan banding.

Demikian pula menurut Pasal 1 butir 12 KUHAP yaitu hak terdakwa atau penuntut umum untuk tidak menerima putusan pengadilan yang berupa perlawanan atau banding atau kasasi atau hak terpidana untuk mengajukan permohonan peninjauan kembali dalam hal serta menurut cara yang diatur dalam undang-undang ini. Selain itu tersangka atau terdakwa atau ahli warinya bisa melakukan permintaan ganti rugi kepada Negara. Permintaan ganti rufi tersebut sebagai wujud dari perlindungan hak asai dan harkat dan martabatnya apabila tersangka atau terdakwa telah mendapat perlakuan yang tidak sah atau tindakan tanpa alasan berdasar undang-undang. Menurut Pasal 1 angka 22 KUHAP permintaan ganti rugi adalah hak seseorang untuk mendapat pemenuhan atas tuntuannya yang berupa imbalan sejumlah uang karena ditangkap, ditahan, dituntut ataupun diadili tanpa alasan yang berdasarkan undang-undang atau karena kekeliruan mengenai orangnya atau hukum yang diterapkan menurut cara yang diatur dalam undang-undang ini.

Rehabilitasi merupakan hak yang dapat diupayakan oleh tersangka atau terdakwa apabila oleh pegadilan diputus bebas atau diputus lepas dari segala tuntutan hukum yang putusannya telah mempunyai kekuatan hukum tetap. Pada Pasal 1 angka 23 KUHAP menerangkan bahwa rehabilitasi adalah hak seseoang untuk mendapat pemulihan haknya dalam kemampuan, kedudukan dan harkat dan martabatnya yang 
diberikan pada tingkat penyidikan, penunutan, atau peradilan karena ditangkap, ditahan, dituntut, ataupun diadili tanpa alasan yang berdasarkan undang-undang atau karena kekeliruan mengenani orangnnya atau hukum yang diterapkan menurut cara yang diatur dalam undang-undang ini.

\section{Peradilan yang Fair dalam KUHAP}

Hukum Acara Pidana (Strafprocesrecht), sebagaimana kita ketahui bersama di dalam pembagian hukum pidana digolongkan .sebagai hukum pidana formal yang berfungsi antara lain sebagai saranuntuk terwujudnya hukum pidana material. Walaupun tidak ada kesamaan pendapat di kalangan pakar hukum pidana mengenai pengertian, fungsi dan tujuan dari Hukum Acara Pidana tersebut, namun yang pasti adalah bahwa keberadaan hukum acara pidana itu menjadi dasar dalam proses peradilan pidana, yang mengatur mengenai hak dan kewajiban tersangka atau terdakwa, hak dan kewajiban dari penyidik, hak dan kewajiban dari jaksa penuntut umum, hak dan kewajiban dari hakim, dan hak serta kewajiban advokat (Samosir, 2013: 2). Apabila kita meneliti kembali beberapa pertimbangan yang menjadi alasan disusunnya KUHAP jelaslah bahwa secara singkat KUHAP memiliki lima tujuan (Atmasasmita, 1983: 27) sebagai berikut:

a. Perlindungan atas harkat dan martabat manusia (tersangka atau terdakwa);

b. Perlindungan atas kepentingan hukum dan pemerintahan ;

c. Kodifikasi dan unifikasi hukum acara pidana;

d. Mencapai kesatuan sikap dan tindakan aparat penegak hukum ;

e. Mewujudkan hukum acara pidana yang sesuai dengan Pancasila dan Undang-Undang Dasar 1945

Berkenaan dengan proses peradilan yang fair KUHAP maupun RUU-KUHAP sudah mengatur hak-hak tersangka/terdakwa secara komprehensif. Berikut beberapa hak yang diatur dalam RUU-KUHAP, mulai Pasal 88 - 102.

a. hak untuk segera diperiksa ( satu hari sejak ditangkap atau ditahan);

b. hak untuk segera berkas perkaranya diserahkan ke JPU (60 hari sejak penyidikan dimulai atau 90 hari jika tidak ditahan); 
c. hak untuk segera dibacakan surat dakwaannya (14 hari sejak perkara dilimpahkan oleh penyidik ke JPU);

d. hak untuk segera dilimpahkan perkaranya ke PN (7 hari sejak dibacakan surat dakwaan);

e. hak untuk segera diadili (120 hari sejak ditahan);

f. hak untuk menunjuk Penasehat Hukum

g. hak untuk diberitahu tentang apa yang disangkakan atau didakwakan;

h. berhak untuk memberikan atau menolak memberikan keterangan terkait sangkaan atau dakwaan;

i. hak untuk mendapat bantuan juru bahasa;

j. hak untuk mendapatkan bantuan hukum dalam semua tingkat pemeriksaan

k. hak untuk menghubungi Penasehat Hukum;

1. hak untuk menghubungi dan menerima kunjungan keluarga, guna mendapat jaminan penangguhan penahanan, atau bantuan hukum, ataupun yang tidak ada kaitan dengan perkara;

m. hak untuk mengajukan saksi atau ahli yang akan memberikan keterangan menguntungkan;

n. hak untuk mengajukan tuntutan ganti kerugian.

Dari berbagai hak tersebut ada beberapa yang baru atau bersifat penegasan dari KUHAP sebelumnya. Misalnya hak untuk segera diperiksa atau diadili, yang menetapkan batas waktu, sehingga ada ukuran bagi publik untuk melakukan upaya atau tindakan jika hak tersebut dilanggar. Hanya saja masih menjadi pertanyaan adalah apakah ada aturan untuk melakukan perbaikan jika hak tersebut dilanggar. Hal ini disebabkan adagium bahwa hak yang efektif adalah hak yang jika dilanggar ada mekanisme untuk memperbaikinya (ibi jus ibi remedium).

\section{SIMPULAN}

Proses peradilan yang fair merupakan manifestasi dari pemenuhan terhadap hak-hak asasi manusia (tersangka) baik dalam tahapan penyidikan, persidangan, maupun pada pelaksanaan pemidaan. Hal itu merupakan perwujudan dari Negara hukum itu sendiri dimana pemangku kekuasaan (negara) pun juga aparat hukum harus menjunjung tinggi nilai-nilai kemanusiaan yang teraktualisasikan dalam peraturan 
perundang-undangan (KUHAP). Sejarah mencatat bahwa hak-hak tersangka sejak dulu dikesampingkan oleh aparat penegak hukum terutama dalam proses penyidikan untuk memperoleh informasi yang berkaitan dengan kasus yang ditanganinya. KUHAP sebagai instrument dalam proses penegakan hukum pidana formil memang memberikan perhatian terhadap hak-hak tersangka, hal itu bisa terlihat dalam asas perlakuan yang sama di depan hukum (equality before the law) butir 3a serta pasal 5 ayat (1) undang-undang kekuasaan kehakiman, asas praduga tidak bersalah (Presumption of Innocent), serta asas penagkapan, penahanan, penggeledahan, dan penyitaan dilakukan berdasarkan perintah tertulis pejabat yang berwenang. Dari adanya asas tersebut menegaskan bahwa aparat penegak hukum tidak serta merta menangkap, menahan, menuntut, atau memberikan sanksi pidana tanpa adanya suatu proses yang adil dalam artia bahwa setiap proses atau tahapan dalam penegakan hukum pidana tersebut harus melalui prosedur legal yang akan bermuara pada keadilan procedural.

Postulat moral yang hendak disampaikan dalam proses peradilan fair tidak lain adalah penghargaan terhadap hak-hak kodrati yang melekat pada diri manusia itu sendiri. Pengahrgaan terhdap hak-hak tersebut bisa menjadi menjadi salah satu indikator penting dalam menegakkan hukum pidana untuk mencapai keselarasan, ketertiban dan perlindungan terhadap masyarakat. Sejalan dengan proses peradilan yang fair ada klasul yang mengatakan, maksud yang baik akan bernilai tidak baik (buruk) jika cara yang digunakan tidak baik (tepat/benar). Maka sudah jelas bahwa proses peradilan yang fair merupakan suatu cara atau jalan untuk memanifestasikan keadilan, kepastian, kemanfaatan dari pelaksanaan hukum pidana itu.

\section{DAFTAR REFERENSI}

Andi Sofyan. Hukum Acara Pidana, Cetakan Pertama. Yogyakarta: Rangkang Education, 2013.

Djisman Samosir, Segenggam Hukum Acara Pidana, Cetakan Pertama. Bandung: Nuansa Aulia, 2013.

Eddy O.S. Hiariej, Prinsip-Prinsip Hukum Pidana, Cetakan Pertama, Yogyakarta: Universitas Atma Jaya, 2014. 
Debi Setyo B Y., Dekonstruksi Asas Legalitas Hukum Pidana, Malang, Setara Press, 2014.

Heri Tahir, Proses hukum Yang Adil dalam Sistem Peradilan Pidana di Indonesia, cetakan I .Yogyakarta, Laksbang Pressindo, 2010.

Munir fuady, Sylvia LauraL. Fuady, Hak Asasi Tersangka Pidana, Cetakan Pertama, Jakarta: Prenada Media Group, 2015.

Muladi, Kapita Selekta Sistem Peradilan Pidana, Semarang: UNDIP, 1998.

M. Ali Zaidan, Menuju Pembaharuan Hukum Pidana, Cetakan Pertama Jakarta: Sinar Grafika, 2015.

Munir Fuady, Teori Hukum Pembuktian, Cetakan Kedua, Bandung: Citra Aditya Bakti, 2012.

Mien Rukmini, Perlindungan Ham Melalui Asas Praduga Tidak Bersalah Dan Asas Persaman Kedudukan Dalam Hukum Pada System Peradilan Pidana Indonesia, cetakan pertama, Bandung: Alumni, 2003.

Romli Atmasasmita, Bunga Rampai Hukum Acara PIdana, Cetakan Pertama, Bandung: Binacipta, 1983.

Agus Raharjo, "Mediasi Sebagai Basis Dalam Penyelesaian Perkara Pidana", Mimbar Hukum , Edisi No 1 Vol. 20, (2008),

Bambang Sutiyoso,"Mencari Format Ideal Keadilan Putusan dalam Peradilan", Jurnal Hukum, Edisi No 2 Vol. 17, (2010)

Enrille C. A. Dehoop, "Perlindungan Hak Tersangka/Terdakwa Terorisme Dalam Sistem Peradilan Pidana Indonesia", Jurnal Hukum Unsrat, Edisi No.1 Vol.I, (2013)

Suparman Marzuki, Materi kuliah Hukum Pidana dan HAM MH UII, disampaikan pada tanggal 26 Juli 2018 .

M. Arif Setiawan, Materi kuliah Sistem Peradilan Pidana MH UII, disampaikan pada tanggal 19 April 2018 